\title{
Аналіз результатів лікування хворих із пошкодженнями стравоходу, ускладненими гострим гніӥним медіастинітом
}

\begin{abstract}
Мета роботи: покращити результати лікування хворих із перфорацією стравоходу, ускладненою гострим гнійним медіастинітом. Матеріали і методи. Проаналізовані результати лікування 27 хворих із перфораціями стравоходу, ускладненими гострим гнійним медіастинітом.

Результати досліджень та їх обговорення. Причинами перфорації стравоходу були сторонні тіла - у 9 (33,3 \%) хворих, спонтанний розрив - у 8 (29,6 \%) хворих, ятрогенія - у 5 (18,5 \%) хворих, неспроможність швів після резекції стравоходу і стентування - у 5 (18,5 \%) хворих. Післяопераційна летальність у хворих із пошкодженнями стравоходу, ускладненими гострим гнійним медіастинітом, склала 37,1 \% (померли 10 із 27 хворих). При застосуванні бокової торакотомії післяопераційна летальність склала 50 \% (померли 9 із 18 хворих), при відеоасистованій торакоскопії - 14,3 \% (помер один із 7 хворих). Своєчасна діагностика перфорації стравоходу та гострого гнійного медіастиніту - один із вирішальних факторів у лікуванні даних хворих. Вибір хірургічної тактики індивідуальний в кожному окремому випадку. Основною метою хірургічного лікування $є$ ліквідація гнійно-запального процесу в середостінні та стабілізація стану хворих. При перфорації стравоходу, ускладненій гострим гнійним медіастинітом, розширені операції на стравоході супроводжуються високими показниками післяопераційної летальності, що обмежує їх використання у хворих із сепсисом та поліорганною недостатністю. Зашивання перфорації стравоходу слід проводити для відмежування просвіту стравоходу від клітковини середостіння, локалізації гнійного процесу в середостінні і стабілізації загального стану хворого. Малоінвазивні операційні втручання за допомогою відеоасистованої торакоскопії можуть слугувати операціями вибору у хворих із перфорацією стравоходу при поширених формах гострого гнійного медіастиніту для санації і дренування гнійно-запального процесу в середостінні, стабілізації стану хворих та попередження розвитку септичних ускладнень.
\end{abstract}

Ключові слова: перфорація стравоходу; гострий гнійний медіастиніт.

Постановка проблеми і аналіз останніх досліджень та публікацій. Лікування хворих із пошкодженням стравоходу (ПС) - одна із найскладніших проблем сучасної хірургії. Перфорація стравоходу супроводжується гострим гнійним медіастинітом (ГГМ) у 67-84 \% хворих [1]. У структурі ПС провідне місце належить ятрогенним пошкодженням, які сягають 52,5-80,6 \% [1, 2]. Найчастіше ПС діагностують при проведенні бужування після хімічних опіків у 1-30 \% хворих, пневмокардіодилатації ахалазії кардії - у 0,2$11 \%$, видалення сторонніх тіл - у 0,22-9,35 \%, стентування неоперабельних пухлин - у $7-11 \%$, ендоскопічного склерозування варикозно розширених вен стравоходу - у 1-6 \% хворих [3]. Протягом останніх років спостерігають зростання числа випадків спонтанного розриву стравоходу (синдрому Бурхаве) [4].

При цьому лише 90 \% хворих звертаються за допомогою в перші години від початку захворювання. Основною проблемою пізньої госпіталізації $€$ незнання лікарями первинної ланки особливостей перебігу захворювання, неправильної інтерпретації даних рентгенологічного обстеження, що призводить до пізньої діагностики і знижує ефективність спеціалізованої хірургічної допомоги [5]. Диференційну діагностику ПС необхід- но проводити з пневмонією, спонтанним пневмотораксом, гемопневмотораксом, абсцесом легень, інфарктом міокарда, гострим панкреатитом, гострим холециститом, розшаруванням аневризми аорти, тромбоемболією легеневої артерії, перфоративною виразкою, перикардитом, мезентеріальним тромбозом, діафрагмальною грижею, інфарктом селезінки, спонтанною емфіземою середостіння $[6,7]$. Закономірно, що таке розмаїття захворювань, які можуть симулювати ПС, створює значні труднощі при діагностиці та у вибоpi адекватної хірургічної тактики. Як наслідок, у хворих часто розвиваються гнійні ускладнення, зумовлені скелетотопією стравоходу в середостінні та анатомічною будовою його стінки. Вже через 6 год після ПС при гістологічному дослідженні у стінці стравоходу виявляють гнійну інфільтрацію всіх шарів на фоні численних крововиливів $[1,4,7]$. Через добу після ПС краї дефекту набувають сірого кольору, при натисканні $з$ рани виділяється гній, а гістологічна картина характеризується різким повнокров'ям та дифузною інфільтрацією тканин нейтрофільними лейкоцитами [6]. Через 12-24 год після ПС виникає розгорнута клінічна картина ГГМ і сепсису [7]. Летальність при ПС ускладнених ГГМ сягає $40,9-80 \%$ [8]. 
Вибір хірургічної тактики у хворих при ПС, ускладнених ГГМ, залишається предметом дискусії. Згідно $з$ даними ряду авторів, на сьогодні відсутня єдина тактика хірургічного лікування ПС, ускладнених ГГМ $[9,10]$. Тяжка ендогенна інтоксикація, порушення гемостазу, поліорганна дисфункція - все це обмежує об'єм операційного втручання. Тому частина авторів рекомендує лише дренування гнійного вогнища та плевральної порожнини [11]. Інші дослідники рекомендують доповнювати дренування клітковини середостіння в ділянці ПС “виключенням” стравоходу з травлення шляхом накладання езофагостоми на шиї та лігатурного виключення стравоходу на рівні стравохідно-кардіального переходу з накладанням гастростоми [10]. Деякі автори вказують на обнадійливі результати зашивання рани стравоходу, незалежно від строків перфорації [9]. Ряд авторів переконаний, що при розвитку ГГМ зашивання рани стравоходу не має змісту, через “запрограмовану” неспроможність швів [10]. Водночас є і прихильники застосування радикального операційного втручання - резекції стравоходу $[10,11]$.

За даними ряду авторів, післяопераційна летальність у хворих із ПС та ГГМ сягає 38,9 \% і коливається залежно від виду операційного втручання. Після накладання гастростоми летальність становить $50 \%$, єюностоми - $100 \%$, зашивання рани стравоходу - 8,8 \%, резекції стравоходу $25 \%$, резекції стравоходу з черевно-шийного доступу - 77,7 \% [8].

Мета роботи: покращити результати лікування хворих із пошкодженнями стравоходу, ускладненими гострим гнійним медіастинітом.

Матеріали і методи. 3а 2000-2017 pp. на лікуванні у відділенні торакальної хірургії ІваноФранківської обласної лікарні перебували 87 хворих із ПС, із них ГГМ діагностований у 27 (31,2\%) пацієнтів. Серед 27 хворих із ПС, ускладнених ГГМ - 18 (66,6 \%) чоловіків, 9 (33,4 \%) жінок віком від 23 до 72 років, у середньому 48,4 року.

Результати досліджень та їх обговорення. Серед 27 хворих причинами ПС були сторонні тіла стравоходу - у 9 (33,3 \%) хворих, спонтанний розрив стравоходу (синдром Бурхаве) - у 8 (29,6 \%) хворих, ятрогенні пошкодження - у 5 (18,5 \%) хворих, неспроможність швів після резекції стравоходу - у 3 (11,1 \%) хворих, неспроможність швів після резекції дивертикула стравоходу - у одного хворого, стентування стравоходу при пухлинному процесі - у одного хворого.
На першу добу від початку захворювання у спеціалізоване відділення госпіталізовано лише 7 (25,9 \%) хворих, на 2-гу добу - 12 (44,4 \%) хворих, у 3-тю добу - 8 (29,6 \%) хворих. Отже, 20 (74,1 \%) хворих із ПС госпіталізовані у пізні строки захворювання.

ПС шийного відділу стравоходу діагностовано у 6 (22,2 \%) хворих, разом верхньогрудного відділу - у 4 (14,8 \%) хворих, середньогрудного - у 6 (22,2 \%) хворих, нижнього відділу стравоходу - у $11(40,7 \%)$ хворих.

За поширенням гнійного процесу в середостінні тотальний ГГМ виявлено у 12 (44,4 \%) хворих, нижній - у 10 (37\%) хворих, верхній - у 5 (18,6 \%) хворих. При цьому серед 15 хворих із верхнім та нижнім ГГМ у 10 (66,6 \%) були обмежені форми гнійного процесу, локалізованого у місці ПС, у 5 (33,4 \%) поширення гною було характерне для флегмони. Слід зазначити, що у хворих із ПС, спричиненою сторонніми тілами, обмежений ГГМ діагностовано у 5 (55,5 \%) із 9 хворих, при синдромі Бурхаве - у 4 (50 \%) та в одного хворого при ятрогенному пошкодженні стравоходу. У решти хворих спостерігали тотальний та поширені форми ГГМ без ознак відмежування гнійно-некротичного запалення.

Обмежені форми ГГМ спостерігали у 5 (71,4 \%) із 7 хворих, які госпіталізовані в першу добу від початку захворювання, та у 5 (41,6 \%) із 12 хворих, які госпіталізовані на 2-гу добу. У всіх хворих, які госпіталізовані на 3-тю добу, спостерігали поширені форми ГГМ. Очевидно, що “фактор часу” від початку захворювання до надання спеціалізованої допомоги хворим із ПС має вирішальне значення щодо розвитку поширених форм ГГМ.

У 21 (87,8 \%) хворого клінічна картина захворювання розвивалася блискавично. Раптово, серед повного здоров'я, виникав різкий біль за грудниною. Інтенсивність болю за грудниною була настільки значною, що застосування наркотичних анальгетиків було малоефективним. У 11 (40,7 \%) хворих біль іррадіював у надчеревну ділянку, хребет, міжлопаткову ділянку, посилювався при ковтанні і блюванні. Посилення болю при ковтанні спостерігали в 7 (25,9 \%) хворих, багаторазове блювання без нудоти - у 8 (29,6 \%) хворих. Симптом Хаммана (потріскуючий звук при аускультації серця, зумовлений накопиченням повітря у середостінні) спостерігали в 12 (44,4 \%) хворих. Емфізему середостіння, яка проявлялася крепітацією при пальпації над яремною ямкою, шиї та обличчя, діагностовано у 12 (44,4 \%) хворих.

При ПС та медіастинальної плеври гнійний процес швидко поширювався у плевральну по- 
рожнину зі стрімким розвитком емпієми плеври та піопневмотораксу. В клінічній картині переважали інтенсивний біль в грудній клітці на сторонні ураження - у 21 (78,5 \%) хворого, задишка і швидко наростаюча дихальна недостатність - у 24 (88,8 \%) хворих.

Основним діагностичними методами були оглядова рентгенографія органів грудної клітки, контрастна рентгенографія стравоходу, ЕГДС, ультразвукова діагностика (УЗД) та спіральна комп’ютерна томографія (CKT). Непрямими ознаками ПС на оглядовій рентгенографії ОГК були розширення тіні середостіння - у 12 (44,4 \%) хворих, рідинні скупчення у плевральних порожнинах - у 25 (92,6 \%) хворих, емфізема середостіння - у 24 (88,8 \%) хворих. За даними УЗД, у всіх хворих із ПС спостерігали появу плеврального ексудату. Серед 27 хворих піопневмоторакс діагностовано у 13 (48,1 \%) хворих, емпієму плеври - у 8 (29,6 \%) хворих, ексудативний плеврит - у 6 (22,2 \%) хворих.

При контрастній рентгенографії і -скопії стравоходу водорозчинним контрастом, витік його за межі стравоходу встановлено у 23 (85,2 \%) хворих. При ЕГДС перфоративний отвір стравоходу виявлено у 22 (81,5 \%) хворих. Важливим діагностичним методом діагностики ПС, ускладнених ГГМ, вважали СКТ ОГК із контрастуванням стравоходу водорозчинним контрастом. Метод був застосований у 9 (24,3 \%) хворих, у яких при попередньому проведенні оглядової рентгенографії та ЕГДС не було доведено факт ПС, а також з метою топічної діагностики рівня перфорації та характеру ГГМ.

Всі хворі із ПС та ГГМ були прооперовані (табл. 1).

Бокову торакотомію, медіастинотомію, зашивання перфоративного отвору стравоходу із дренуванням середостіння та плевральної порожнини 3-4 дренажами за Бюлау провели у 11 (40,7 \%) хворих (померли 4, післяопераційна летальність 36,4 \%). Цей вид операційного втручання застосували у хворих при ранніх термінах від початку за- хворювання і при тотальних ГГМ із ознаками тяжкого сепсису і поліорганної недостатності (ПОН). На нашу думку, розширення обсягу операційного втручання з метою накладання гастростоми не завжди виправдане, адже супроводжується додатковою травмою, збільшує анестезіологічний ризик, що може створити пряму загрозу для життя хворого. Харчування хворих у ранній період після таких операцій проводили парентерально та через назогастральний зонд, а з 2-го тижня доповнювали частковим ентеральним харчуванням за відсутності стравохідно-плевральної нориці.

Бокову торакотомію, медіастинотомію та дренування середостіння як “операцію відчаю” виконали у 2 (7,4 \%) хворих (померли 2, післяопераційна летальність - 100 \%). Цю операцію виконували за вкрай тяжкого стану хворих, при тотальному ГГМ та ПОН. Проведення додаткових операцій 3 метою “виключення” стравоходу було неможливе через критичний стан пацієнтів.

Бокову торакотомію, зашивання ПС та накладання езофагостоми і гастростоми за Кадером провели у 2 (7,4%) хворих, післяопераційна летальність склала 100 \%. Це були хворі із ПС на грунті синдрому Бурхаве (1) і неспроможності швів езофагоентероанастомозу (1), яку діагностували на 3-й день після операції Люїса на фоні клініки тотального ГГМ.

Бокову торакотомію, медіастинотомію, зашивання ПС та накладання гастростоми за Кадером застосували у 3 (11,1%) хворих (помер один хворий, післяопераційна летальність склала 33,3 \%). Причиною смерті стали тотальний ГГМ, піопневмоторакс, сепсис та ПОН.

Цервікотомію за Разумовським, медіастинотомію, розкриття верхнього середостіння, зашивання ПС та дренування плевральної порожнини 2-3 дренажами за Бюлау виконали у 2 (7,4 \%) хворих (післяопераційна летальність - 0 \%). Це були хворі з обмеженим ГГМ, який поширювався лише в межах верхнього середостіння і не супроводжувався ознаками сепсису чи ПОН.

Таблиця 1. Характер операційних втручань у хворих із перфорацією стравоходу, ускладненою гострим гнійним медіастинітом

\begin{tabular}{||l|c|c||}
\hline \multicolumn{1}{|c|}{ Вид операційного втручання } & Число хворих, n=27 & Померли, $\mathrm{n}=10$ \\
\hline Торакотомія+зашивання ПС+дренування & $11(40,7 \%)$ & $4(36,4 \%)$ \\
\hline Торакотомія+дренування & $2(7,4 \%)$ & $2(100 \%)$ \\
\hline Торакотомія+зашивання ПС+гастростомія & $3(11,1 \%)$ & $1(33,3 \%)$ \\
\hline Торакотомія+зашивання ПС+гастростомія+езофагостомія & $2(7,4 \%)$ & $2(100 \%)$ \\
\hline Відеоасистована торакоскопія+дренування & $7(25,9 \%)$ & $1(14,3 \%)$ \\
\hline Цервікотомія+медіастинотомія+зашивання ПС+дренування & $2(7,4 \%)$ & - \\
\hline Разом & $27(100 \%)$ & $10(37,1 \%)$ \\
\hline
\end{tabular}


При виконанні бокової торакотомії нагноєння післяопераційної рани мало місце у 6 (33,3 \%) із 18 хворих.

Дискутабельним залишається питання зашивання ПС. За нашим досвідом, зашивання ПС не показане при гнійному розплавленні стінки стравоходу в умовах тотального ГГМ і при пізній госпіталізації хворих. В інших випадках зашивання ПС ми вважаємо доцільним і виправданим. Навіть при виникненні неспроможності швів в ділянці ПС, відмежування просвіту стравоходу від клітковини середостіння дозволяє запобігти його реінфікуванню, сприяє локалізації гнійного процесу у середостінні, стабілізації загального стану хворого за рахунок зменшення ознак гнійної інтоксикації і ПОН.

Так, у 18 (66,6 \%) хворих ми провели зашивання ПС 2-рядним вузловим швом нитками “Вікрил” 3,0 чи “Дексон” II, неспроможність швів було виявлено у 11 (61,1 \%) хворих, з них у 8 (72,7 \%) розмір перфоративного отвору стравоходу зменшився за даними контрастної езофагографії, що покращувало прогноз захворювання.

Відеоасистовану торакоскопію (ВАТС) при ПС застосували у 7 (25,9 \%) хворих (помер один хворий, післяопераційна летальність склала 14,3 \%). Перевагами ВАТС вважаємо мінімальну операційну травму, скорочення часу проведення операції. Особливої актуальності ця складова ВАТС набуває за умов проведення операційного втручання при тяжкому стані хворого, в умовах ГГМ і сепсису. Іншою перевагою ВАТС $є$ мінімізація проблеми нагноєння післяопераційної рани в місцях накладання портів. При ВАТС в стислий термін (20-40 хв) можна провести ефективне дренування - параезофагеальної і медіастинальної клітковини та плевральної порожнини.

Узагальнюючи наш невеликий досвід застосування ВАТС у хворих із ПС, ускладнених ГГМ, вважаємо, що даний метод, безсумнівно, має пріоритети перед торакотомією. За встановленого діагнозу ПС, ускладненого ГГМ, малоінвазивне операційне втручання в ряді випадків може забезпечити достатній радикалізм втручання при мінімальній травматичності. В діагностично складних ситуаціях ВАТС повинен стати методом вибору для остаточного визначення хірургічної тактики лікування.

Показаннями до проведення ВАТС вважаємо поширене гнійне ураження клітковини середостіння із гнійним розплавленням стінки стравоходу, при значних дефектах його стінки, протяжністю більше 7-8 см, прогнозовану неспроможність швів стравоходу в умовах тотального ГГМ, за наявності ПОН, у хворих із V ступенем анестезіологічного ризику. Застосування ВАТС виправда- не при ПС, ускладнених обмеженим ГГМ, а також при піопневмотораксі чи емпіємі плеври.

Метою ВАТС слід вважати санацію і дренування параезофагеальної клітковини і клітковини середостіння. Обов'язкове дренування плевральної порожнини проводили 2-3 дренажами за Бюлау. Вказане дозволяло локалізувати гнійний процес у середостінні і плевральній порожнині, досягнути швидкого розправлення колабованої легені, стабілізувати стан хворого. За цих умов на 3-4 тиждень після операції формувалася стравохідно-плевральна нориця, яка через 3-4 тижні закривалася самостійно. Зашивання функціонуючої стравохідноплевральної нориці показане при повній ліквідації запального процесу в середостінні і плевральній порожнині при функціонуванні стравохідно-плевральної нориці після 4 тижнів від моменту ПС із використанням бокової торакотомії. Операційне втручання включало висічення норицевого ходу та зашивання дворядним вузловим швом окремо слизової оболонки та м'язового шару стравоходу.

Післяопераційна летальність у хворих із пошкодженнями стравоходу, ускладненими гострим гнійним медіастинітом, склала 37,1 \% (померли 10 із 27 хворих). При застосуванні бокової торакотомії післяопераційна летальність склала 50 \% (померли 9 із 18 хворих), при відеоасистованій торакоскопії - 14,3 \% (помер один із 7 хворих).

Перспективи подалыших досліджень. Вибір хірургічної тактики лікування перфорацій стравоходу в умовах гнійного медіастиніту є вирішальним в успішному лікуванні хворих. Перспективою подальших досліджень $є$ вдосконалення хірургічного лікування ПС та методів дренування середостіння, розробка хірургічної тактики лікування ПС залежно від термінів перфорації та поширення гнійного процесу в середостінні.

Висновки. 1. Своєчасна діагностика перфорації стравоходу та гострого гнійного медіастиніту $є$ одним із вирішальних факторів у лікуванні даних хворих.

2. Вибір хірургічної тактики повинен буди індивідуальний в кожному окремому випадку. Основною метою хірургічного лікування є ліквідація гнійно-запального процесу в середостінні та стабілізація стану хворих.

3. При перфорації стравоходу, ускладненій гострим гнійним медіастинітом, розширені операції на стравоході супроводжуються високими показниками післяопераційної летальності, що обмежує їх використання у хворих із сепсисом та поліорганною недостатністю. 
4. Зашивання перфорації стравоходу слід проводити для відмежування просвіту стравоходу від клітковини середостіння, локалізації гнійного процесу у середостінні і стабілізації загального стану хворого.

5. Малоінвазивні операційні втручання за допомогою відеоасистованої торакоскопії можуть слугувати операціями вибору у хворих із перфорацією стравоходу при поширених формах гострого гнійного медіастиніту для санації і дренування гнійно-запального процесу в середостінні, стабілізації стану хворих та попередження розвитку септичних ускладнень.

\section{СПИСОК ЛІТЕРАТУРИ}

1. Лечение травматических повреждений пищевода / М. А. Можейко, Н. И. Батвинков, А. А. Сушко, Є. В. Могилевец // Журнал Гродненского государственного медицинского университета. - 2013. - № 2. - С. 28-31.

2. Дробязгин Е. А. Диагностика и лечение пациентов с инструментальной перфорацией пищевода / Е. А. Дробязгин, Ю.В.Чикинев, М. С. Аникина // Вестник хирургии. - 2016. - С. 64-67.

3. Incidence, clinical management and outcomes of esophageal perforations after endoscopic dilatation / L. C. Fry, K. Mönkemüller, H. Neumann [et al.] // Z. Gastroenterol. - 2007. - No. 45. - P. 1180-1184.

4. Плаксин С. А. Хирургическая тактика при ятрогенных повреждениях пищевода вследствие лечебно-диагностических вмешательств / С. А. Плаксин, Л. П. Котельникова, Е. Е. Саблин // Пермский медицинский журнал. - 2017. T. XXXIV, № 6. - C. 12-21.

5. Шевчук I. М. Причини, шляхи поширення та діагностичні помилки у хворих із низхідним гнійним медіастинітом / I. М. Шевчук, С. С. Сніжко, М. Г. Шевчук // Український журнал хірургії. - 2017. - № 4 (35). - С. 47-51.

\section{REFERENCES}

1. Mozheyko, M.A., Batvinkov, N.I., Sushko A.A., \& Mogilevets E.V. (2013). Lechenie travmaticheskikh povrezhdeniy pishchevoda [Treatment of traumatic damages of the esophagus]. Zhurnal Grodnenskogo gosudarstvennogo meditsinskogo universiteta - Jornal of Grodno State Medical University, 2, 28-31 [in Russian].

2. Drobyazgin, E.A., Chikenev, Yu.V., \& Anikina, M.S. (2016). Diagnostika i lechenie patsiyentov s instrumentalnoy perforatsiyey pishchevoda [Diagnostic and treatment of the patients with instrumental damages of the esophagus]. Vestnik khirurgii - Surgical News, 64-67 [in Russian].

3. Fry, L.C., Mönkemüller, K., \& Neumann H. (2007). Incidence, clinical management and outcomes of esophageal perforations after endoscopic dilatation. Z. Gastroenterol., 45, 1180-1184.

4. Plaksin, S.A., Kotelnikova, L.P., \& Sablin, E.E. (2017). Khirurgicheskaya taktika pri yatrogennikh povrezhdeniyakh pishchevoda [Surgical tactics with yatrogenic damages of the esophagus]. Permskiy meditsinskiy zhurnal - Medical Jornal of Perm, XXXIV, 6, 12-21 [in Russian].

5. Shevchuk, I.M., Snizhko, S.S., \& Shevchuk M.G. (2017). Prychyny, shliakhy poshyrennia ta diahnostychni pomylky u khvorykh iz nykhidnym hniinym mediastinitom. [Causes, pathways and diagnostic errors in patients with descended purulent mediastinitis]. Ukrainskyi zhurnal khirurhii - Ukrainian

Journal of Surgery, 4 (35), 47-51 [in Ukrainian].

6. Vogel, S.B. Rout, W.R., \& Martin, T.D. (2005). Esophageal perforation in adults: aggressive, conservative treatment lowers morbidity and mortality. Ann. Surg., 241, 1016-1021.

7. Skvortsov, M.B., \& Borichevskiy, V.I. (2007). Rol mediastinita i yego profilaktika pri lechenii perforatsii pishchevoda [Role of mediastinatis and prophylaxis in treatment of esophageal perforation]. Byuleten VSNC RAMN - Bulletin of VSNC RAMS, 4 (56), 23-27 [in Russian].

8. Shestyuk, A.M., Karpitskiy, A.S., \& Panko, S.V. (2010). Pronikayushchie povrezhdeniya grudnogo otdela pishchevoda: sovremennoye sostoyanie problemy [Penetrating wounds of the thoracic part of esophagus. Modern condition of problem]. Novosti khirurgii - Surgery News, 3 (18), 130-136 [in Russian].

9. De Lutio di Castelguidone, Pinto, A., \& Merola, S. (2006). Esophageal injuries: Spectrum or multidetector row CT findings. Eur. J. Radiol., 59, 344-348.

10. Ostapenko, G.O., \& Lishov, E.V. (2008). Khirurgicheskoe lechenie perforatsii grudnogo otdela pishchevoda oslozhnionnykh difuznym gnoynym mediastinitom [Surgical treatment penetrating wounds of the esophagus with purulent mediastinatis]. Sibirskiy meditsinskii zhurnal - Siberian Medical Journal, 1, 43-46 [in Russian].

11. Kimchi, E.T., Staveley, K.F., \& Carroll, O. (2006). Esophageal Perforation. J. Optechgensurg, 156-160. 


\section{ANALYSIS OF TREATMENT OUTCOMES OF PATIENTS WITH PERFORATIONS OF THE ESOPHAGUS, COMPLICATED BY ACUTE PURULENT MEDIASTINITIS}

The aim of the work: improving the treatment outcome of patients with perforation of the esophagus, which is complicated by acute purulent mediastinitis.

Materials and Methods. The results of treatment of 27 patients were analyzed.

Results and Discussion. The causes of perforation of the esophagus were foreign bodies in 9 (33.3 \%), spontaneous rupture - in 8 (29.6\%), iatrogenic - in 5 (18.5\%), failure of sutures after resection of the esophagus and stenting - in 5 (18.5\%). Postoperative lethality in patients with perforation of the esophagus complicated by acute purulent mediastinitis was $37.1 \%$ (10 among 27 patients died). In the application of lateral thoracotomy, postoperative lethality was $50 \%$ (9 among 18 patients died), with video-assisted thoracoscopy $14.3 \%$ (1 among 7 patients died).

Timely diagnosis of perforation of the esophagus and acute purulent mediastinitis is one of the decisive factors in the treatment of these patients. The choice of surgical tactics should be individual in each individual case. The main purpose of surgical treatment is to eliminate the purulent-inflammatory process in the mediastinum and stabilize the condition of the patients. With perforation of the esophagus, which is complicated by acute purulent mediastinitis, expanded operations in the esophagus are accompanied by high rates of postoperative lethality, which limits their use in patients with sepsis and multiple organ failure. Stitching of the perforation of the esophagus should be performed to distinguish the esophageal lumen from the mediastinal fluid, localization of the purulent process in the mediastinum, and to stabilize the general condition of the patient. Minimal invasive surgical interventions using video-assisted thoracoscopy can serve as a selection option in patients with perforation of the esophagus in the common forms of acute purulent mediastinitis for the sanation and drainage of the purulent-inflammatory process in the mediastinum, stabilization of the patient's condition and prevention of septic complications.

Key words: perforation of the esophagus; acute purulent mediastinitis.

\section{И. М. ШЕВЧУК, С. С. СНИЖКО}

гВУз “Ивано-Франковский национальный медицинский университет”

\section{АНАЛИЗ РЕЗУЛЬТАТОВ ЛЕЧЕНИЯ БОЛЬНЫХ С ПОВРЕЖДЕНИЯМИ ПИЩЕВОДА, ОС.ЛОЖНЕННЫМИ ОСТРЫМ ГНОЙНЫМ МЕДИАСТИНИТОМ}

Цель работы: улучшить результаты лечения больных с перфорацией пищевода, осложненной острым гнойным медиастинитом. Материалы и методы. Проанализированы результаты лечения 27 больных.

Результаты исследований и их обсуждение. Причины перфорации пищевода были инородные тела - у 9 (33,3 \%) больных, спонтанный разрыв - у 8 (29,6 \%) больных, ятрогения - у 5 (18,5 \%) больных, несостоятельность швов после резекции пищевода и стентирование - у 5 (18,5 \%) больных. Послеоперационная летальность у больных с повреждениями пищевода, осложненными острым гнойным медиастинитом, составила 37,1 \% (умерли 10 из 27 больных). При применении боковой торакотомии послеоперационная летальность составила 50 \% (умерли 9 из 18 больных), при видеоасистированной торакоскопии - 14,3 \% (умер один с 7 больных).

Своевременная диагностика перфорации пищевода и острого гнойного медиастинита является одним из решающих факторов в лечении этих больных. Выбор хирургической тактики должен быть индивидуальный в каждом отдельном случае. Основной целью хирургического лечения является ликвидация гнойно-воспалительного процесса в средостении и стабилизация состояния больных. При перфорации пищевода, осложненной острым гнойным медиастинитом, расширенные операции на пищеводе сопровождаются высокими показателями послеоперационной летальности, что ограничивает их использование у больных с сепсисом и полиорганной недостаточностью. Зашивания перфорации пищевода следует проводить для ограничения просвета пищевода от клетчатки средостения, локализации гнойного процесса в средостении и стабилизации общего состояния больного. Малоинвазивные операционные вмешательства с помощью видеоасистированной торакоскопии могут служить операциями выбора у больных с перфорацией пищевода при распространенных формах острого гнойного медиастинита для санации и дренирования гнойно-воспалительного процесса в средостении, стабилизации состояния больных и предупреждения развития септических осложнений.

Ключевые слова: перфорация пищевода; острый гнойный медиастинит. 